\title{
Bio-chemical properties and susceptibility to fire blight (Erwinia amylovora Burrill) of scab-resistant apple cultivars (Malus domestica Borkh.)
}

\author{
Boban S. Đorđevič*, Dejan B. Đurović, \\ Gordan D. Zec, Aleksandar B. Radović, Todor B. Vulić
}

Faculty of Agriculture University of Belgrade

Nemanjina 6, Belgrade 11080, Serbia

\begin{abstract}
The focus of our research was to evaluate different apples cultivars in terms of their biological properties and bioactive compounds content, and determine the levels of their resistance (or susceptibility) to fire blight. The properties of 10 scab-resistant apple cultivars were examined on the Žiča monastery estate (West Serbia) during the period from 2011 to 2015. The biological and chemical properties such as firmness, maturity stage, total soluble solids, total acids, total and reducing sugars, ascorbic acid content and surface blush of apple fruits were monitored. Various phenolic compounds in the tested samples were tentatively identified by LC-MS analyses. A study of generative properties included: number of flower buds, fruit mass and width, crop load, yield efficiency and yield. During the period of blooming and intensive shoot growth, artificial inoculations were carried out. For each cultivar, a fire blight score was determined by dividing the average length of necrotic tissue by the average total shoot length. In the study period, the cultivars 'GoldRush' (41.1 t ha $\left.{ }^{-1}\right)$ and 'Florina' (35.9 t ha $\left.{ }^{-1}\right)$ produced the highest yields, and the cultivars 'Discovery' (19.0 $\left.\mathrm{t} \mathrm{ha}^{-1}\right)$ and Selection 25/63 (15.1 tha $\left.{ }^{-1}\right)$ the lowest. The cultivar 'William's Pride' produced the largest fruits, with an average fruit mass of $206.8 \mathrm{~g}$. The earliest harvest period was recorded for the cultivar 'Discovery' (end of July), and the latest for the cultivar 'GoldRush'

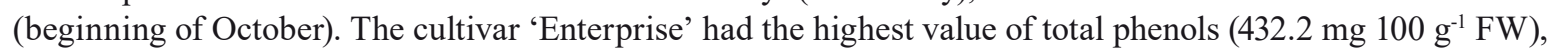
while the cultivar 'Topaz' had the highest value of total flavanols (145.2 mg $\left.100 \mathrm{~g}^{-1} \mathrm{FW}\right)$. The highest degree of susceptibility to fire blight was found in Selection 25/63, and the greatest resistance was manifested by the cultivar 'GoldRush'. In the five-year study period, the cultivars 'GoldRush', 'Rewena' and 'Enterprise' exhibited better bio-chemical properties and higher levels of resistance to fire blight than the remaining cultivars.
\end{abstract}

Key words: flavanols, phenols, soluble solids, susceptibility, yield efficiency

\section{INTRODUCTION}

The apple (Malus domestica Borkh.) is the most important of all deciduous tree fruits in terms of production volume and a focus of research worldwide (Jackson, 2000). According to Mikulic et al. (2007), the main apple cultivars in Europe are still 'Golden Delicious', 'Jonagold', 'Gala' and 'Red Delicious'. These cultivars are known for their excellent quality and are highly desired by consumers. However, they are susceptible to apple scab and need several sprayings with fungicides to ensure high quality

\footnotetext{
*Corresponding author. 
fruits. Planting scab-resistant cultivars minimizes environmental damage by reducing the need for chemical spraying. Growing scab-resistant cultivars decreases the use of pesticides (Kühn et al., 2003) and increases the level of competitiveness of apple production (Beber, 2009).

In recent decades, according to Lauri et al. (2004), the use of intensive apple orchards has been proposed to improve profitability and yield, notably of early cropping cultivars. The apple fruit yield depends on 2 factors - the number of fruits and their size. Crop load, defined as the number of fruits per tree, has a significant impact on both fruit quality and tree physiology (Treder et al., 2010). The growers of apple fruits are under increasing pressure to increase fruit size to satisfy consumer demands, but profitability in an apple orchard also depends on the optimal yield and high fruit quality (Radivojević et al., 2014).

The quality of apples, in terms of the amounts of chemical compounds in the fruit, varies even within the same cultivar, depending on fruit maturity, location of production, technological practices, as well as on agro-ecological environmental conditions (Veberic et al., 2005). The maturity stage of fruits is a very important factor which influences the inner quality of apples, because harvesting at the right maturity stage is important for optimum quality and especially for the preservation of this quality after harvest and storage (Tavarini et al., 2008). Phenolic compounds, like all natural secondary metabolites of plants, determine the outer and inner quality parameters of fruits. Phenolic compounds have numerous important bioactive roles in the plant defence mechanism as well as in antioxidant expression in the plant (Veberic et al., 2005). The phenolic composition of plant tissue can improve the level of susceptibility and tolerance to fungal infections and pests (Usenik et al., 2004; Li et al., 2008).

The necrogenic Gram-negative bacteria Erwinia amylovora (Burrill), which causes fire blight, has been regarded in the last few decades as one of the most economically important diseases in apple production. According to Mikicinski et al. (2015), flowers are the most important site of infection for epidemic fire blight occurrence, followed by the young growing shoots. Also, the authors stated that the pathogen enters host plants via natural openings such as the stigmas and nectaries of flowers, stomata, hydathodes, or via wounds, and spreads systemically within plants. In the environmental conditions of warm and humid regions, an epidemic of fire blight is more severe than in colder and dry areas.

The interest in finding new possibilities and technological practices for fire blight control has increased. The control measures used in fire blight affected areas have consisted in the removal of diseased host plants or their parts, suitable cultural practices, and application of chemical sprays (Korba et al., 2008). According to Vanneste (2000), chemical control of fire blight is unsatisfactory, and so are modern orchard management practices, such as high tree planting density. Also, mechanical pruning in the spring/summer period results in an increased vulnerability of orchards. Therefore, the need for fire blight-resistant cultivars of fruit and ornamental trees is more pressing than ever (Korba et al., 2008).

In the Republic of Serbia, apple production is of great importance for the country's agriculture. With an annual production of 400,000 tons of apples, it is in second place in total fruits productions in Serbia. Modern agricultural practices in Serbian apple production have significantly reduced the numbers of local cultivars and most of them have nearly disappeared (Mratinić and Fotirić-Akšić, 2011). In our study, we have focused on assessing the biological properties of new scab-resistant apple cultivars in comparison with most of the cultivars grown in Serbia. Also, the second aim was to determine their levels of resistance (or susceptibility) to fire blight.

\section{MATERIALS AND METHODS}

\section{Plant material}

The characteristics of 10 scab-resistant apple cultivars: 'Discovery', 'William's Pride', 'Prima', 'Champion', 'Rewena', 'Remura', 'Topaz', 'Florina', 'Enterprise', 'GoldRush' and one Selection 25/63, along with the cultivar 'Idared', which was used as the control cultivar to compare all the parameters, were studied on the Žiča monastery estate (West Serbia) during the period from 2011 to 2015. The cultivar 'Idared' was chosen as the control because it is the most common cultivar in Serbia and in the top five in terms of annual fruit production in Europe.

The experimental orchard was setup in autumn 2009 , with planting distance of $3.5 \times 1.25 \mathrm{~m}$ between virus-free seedlings. All cultivars were grafted on rootstock M9 clone Pajam 2.

\section{Weather conditions}

Measurements of environmental conditions included the parameters of air temperature, relative 
humidity and precipitation. The air temperature and relative humidity were measured at a height of $2 \mathrm{~m}$ using automatic weather stations (Meteos Compact; Pessl Instruments $\mathrm{GmbH}$ ) set in the immediate vicinity of the planting (Šavikin et al., 2013). The highest average temperature was in 2012 (Tab. 1). Also in that year, the average maximum temperature was the highest. The average minimum temperature was the lowest in 2014. Also, a record cumulative precipitation in the last one hundred years was recorded in that year. Consequently, the relative humidity percentage was the highest in 2014.

\section{Biological properties}

The main phenological properties examined were the times of blooming and ripening. The beginning of blooming was determined as the time when $10 \%$ of all flowers had opened, and ripening when fruits were at full maturation. The blooming and harvest times were determined as the number of days from the $1^{\text {st }}$ of January. For a period of 5 years, the following generative properties were studied: number of flower buds per tree, fruit mass and width, crop load (fruit $\mathrm{cm}^{-2} \mathrm{TCSA}$ ), yield efficiency ( $\mathrm{kg} \mathrm{cm}^{-2} \mathrm{TCSA}$ ), average yield per tree and per unit land area. To evaluate the generative properties, one hundred trees (five repetitions with twenty trees each) of each cultivar were tested.

\section{Sample preparation}

Sample preparation was done according to Šavikin et al. (2014). Fresh apple fruits were washed with tap water to remove adhering dirt and dust particles, dried with paper towels, and cut into pieces with a stainless steel knife. Apple juice was obtained from a whole fruit (twenty fruits of each cultivar) by using an electric juicer. Then $100 \mathrm{~mL}$ of arbutin in methanol (internal standard) was added to $1 \mathrm{~g}$ of juice and further homogenized with $4 \mathrm{~mL}$ of methanol. The mixture was centrifuged $(4,000 \mathrm{rpm}$ at $25^{\circ} \mathrm{C}$ ) for $20 \mathrm{~min}$. The supernatant was filtered through a $0.45-\mathrm{mm}$ cellulose filter (Millipore,
Billerica, MA, USA) into a vial for LC-MS/MS analysis.

\section{Fruit quality}

The evaluation of fruit quality during the research period included the following properties: fruit firmness, maturity stage, total soluble solids (TSS), total acid (TA), total and invert sugars (TS, IS), sweetness, ascorbic acid (AA) content and surface blush (Šavikin et al., 2014). Five apples from each of the 20 trees of corresponding cultivars were harvested at the commercial maturity stage. Fruit firmness was measured using a Wagner FT penetrometer (Greenwich, CT, USA), and maturity stage was determined by the iodine-starch test (Streif, 1996). Total soluble solids content (TSS) was determined with a PAL-1 refractometer (Atago, Tokyo, Japan) in ${ }^{\circ}$ Brix. Titratable acidity (TA) was measured by neutralization with $0.1 \mathrm{~N} \mathrm{NaOH}$; data are given as $\mathrm{g} \mathrm{dm}^{-3}$ malic acid. Total sugar content (TS) was determined by the Luff-Schoorl method

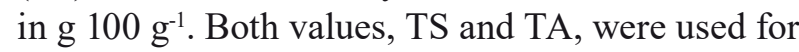
the determination of total sugar/organic acid ratio. An iodometric titration method was performed for the determination of ascorbic acid content (Harris, 2000), and the results were expressed as $\mathrm{mg} 100 \mathrm{~g}^{-1}$ FW.

\section{Phenolic content}

Phenolic content analyses were done during three consecutive years (2013-2015) according to Šavikin et al. (2014). Phenolic compounds in the tested samples were tentatively identified by comparing the retention times, absorption spectra (200-400 $\mathrm{nm}$ ) and mass spectra (in scan mode) of unknown peaks with the reference standards. LC-MS analyses were performed on an Agilent MSD TOF coupled to an Agilent 1200 Series HPLC (Agilent Technologies, Palo Alto, CA, USA). Mobile phase A was water, mobile phase $\mathrm{B}$ acetonitrile, and mobile phase $\mathrm{C} 1 \%$ formic acid in water. The injection volume was $1.5 \mathrm{~mL}$, and elution at $0.5 \mathrm{~mL} \mathrm{~min}{ }^{-1}$ with a gradient program $(0-13.3 \mathrm{~min} .5-16 \% \mathrm{~B}$ and $10 \% \mathrm{C}, 13.3-16$ min. $16-28 \% \mathrm{~B}$ and $10 \% \mathrm{C}, 16-22$

Table 1. Weather conditions during the blooming period (2011-2015)

\begin{tabular}{|c|c|c|c|c|c|}
\hline & 2011 & 2012 & 2013 & 2014 & 2015 \\
\hline Max. T $\left({ }^{\circ} \mathrm{C}\right)$ & 18.5 & 19.1 & 17.4 & 16.2 & 18.1 \\
\hline Min. T $\left({ }^{\circ} \mathrm{C}\right)$ & 9.1 & 8.6 & 7.8 & 7.2 & 8.9 \\
\hline Avg. T $\left({ }^{\circ} \mathrm{C}\right)$ & 14.4 & 14.8 & 13.9 & 13.6 & 14.1 \\
\hline Precipitation (mm) & 84.3 & 77.4 & 65.3 & 176.4 & 92.5 \\
\hline Humidity (\%) & 58.3 & 52.5 & 54.8 & 72.2 & 46.1 \\
\hline
\end{tabular}


min. $28-40 \% \mathrm{~B}$ and $10 \%$ C, $22-23 \min .40-100 \% \mathrm{~B}$ and $10 \%$ C, $23-25$ min. $100 \%$ B, 25-25.1 min. 100 $5 \% \mathrm{~B}$ and $0-10 \% \mathrm{C}, 25.1-33 \mathrm{~min} .5 \% \mathrm{~B}$ and $10 \% \mathrm{C}$ ). The mass spectrometer was operated in positive and negative ESI mode. Drying gas (N2) flow was $800 \mathrm{~L} \mathrm{~h}^{-1}$; drying gas temperature was $400^{\circ} \mathrm{C}$. For ESI analysis, the parameters were: capillary voltage $3,500 \mathrm{~V}$; cone voltage $30 \mathrm{~V}$, source temperature $150^{\circ} \mathrm{C}$ for negative and positive modes. The mass range was from $\mathrm{m} / \mathrm{z} 100$ to 2,000. Multiple reaction monitoring (MRM) mode was used for quantitative analysis of the samples. An internal standard, arbutin, was used to quantify phenolic compounds. Arbutin was added to standard solutions of each compound (five concentrations of each) to make a final internal standard concentration of $25 \mathrm{mg}$ $\mathrm{mL}^{-1}$. The samples prepared as described above under Sample preparation were injected into the LC-MS/MS and the concentrations of phenolic compounds were determined from the standard curves. The samples were analyzed in triplicate.

\section{Erwinia amylovora analysis}

One year after planting, the apple cultivars and selection were tested for resistance to Erwinia amylovora during five consecutive years. Inoculation was performed with a bacterial suspension composed of a few strains of E. amylovora which had been isolated in the Republic of Serbia. Before inoculation, as a confirmation of virulence, the pathogen strains were verified by testing on apples and pears harvested in the previous year.

During the period of blooming and intensive shoot growth, artificial inoculations were carried out. To assess the resistance to fire blight, one hundred trees of each cultivar were sprayed. Four to five times during those periods, at intervals of 5 to 7 days, whole trees were sprayed with a hand-held atomizer. An E. amylovora suspension was at a concentration of approximately 106 cells $\mathrm{ml}^{-1}$. Eighty days after inoculation, when the intensive growth of shoots had ceased, the total number of shoots was counted and the length of each shoot and of the visibly blighted parts of the shoots were measured. A fire blight score for each cultivar was determined by dividing the average length of necrotic tissue by the average total length of one-year old shoots according to Korba et al. (2008). A higher percentage of blighted shoot length indicated a higher level of susceptibility. Based on the percentage blight score, 6 classes of blight resistance were defined: $\mathrm{hR}=$ highly resistant; $\mathrm{R}=$ resistant; $\mathrm{mR}=$ moderately resistant; $\mathrm{mS}=$ moderately susceptible; $\mathrm{S}=$ susceptible; $\mathrm{hS}=$ highly susceptible (Tab. 2).

The experiment was set up in random fields with five repetitions, where 20 trees were taken for a repeat (100 trees of each cultivar were tested). Analysis of variance was done with STATISTICA 7 software package. Separation of means was done by Tukey's lowest significant difference (LSD) test at a 5\% level of significance. Relationships among the investigated fruit parameters were measured using the Pearson correlation coefficient $(r)$, and correlations were considered statistically significant if the $p$-value was less than 0.05 .

\section{RESULTS AND DISCUSSION}

The cultivar 'Topaz' had the earliest average blooming time ( $7^{\text {th }}$ April) and the cultivar 'Rewena' had the latest (22 ${ }^{\text {nd }}$ April). The cultivar 'Discovery' had the earliest harvest time ( $25^{\text {th }}$ July) and the cultivar 'GoldRush' the latest ( $5^{\text {th }}$ October). The shortest time from the beginning of blooming to harvest was in the cultivars 'Discovery' and 'Williams's Pride' (103 and 117 days, respectively) and the longest in 'Topaz' and 'GoldRush' (165 and 177 days, respectively). According to the time of fruit harvesting, three cultivars are early ripening ('Discovery', 'William's Pride' and Selection 25/63), another three are medium ripening ('Prima', 'Champion' and 'Remura'), and five belong to late

Table 2. Blight scores and classes of fire blight resistance

\begin{tabular}{lll}
\hline Percentage of blighted shoot length & Resistance class and its abbreviation & \\
\hline $0.0-7.0$ & highly resistant & $\mathrm{hR}$ \\
$7.1-13.0$ & resistant & $\mathrm{R}$ \\
$13.1-26.0$ & moderately resistant & $\mathrm{mR}$ \\
$26.1-60.0$ & moderately susceptible & $\mathrm{mS}$ \\
$60.1-80.0$ & susceptible & $\mathrm{S}$ \\
$80.1-100$ & highly susceptible & $\mathrm{hS}$ \\
\hline
\end{tabular}




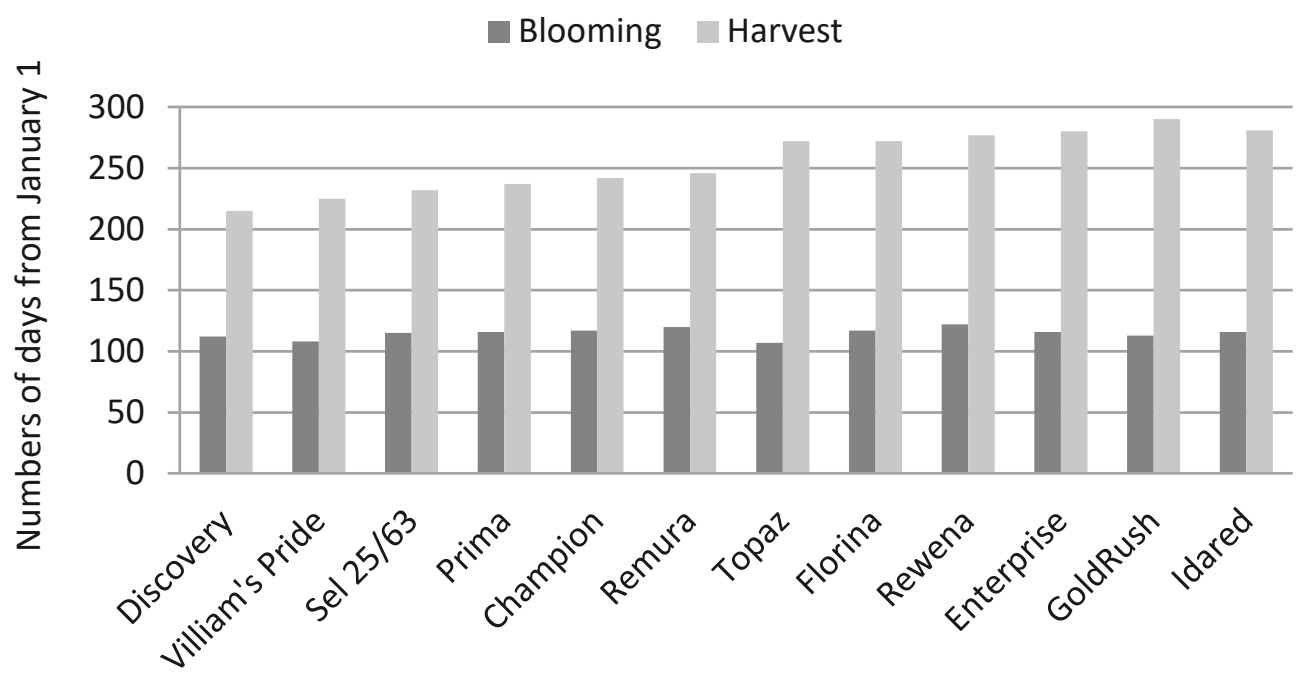

Cultivars

Figure 1. Phenological properties of apple cultivars (2011-2015), the beginning of blooming and full maturation of fruits (counting from the $1^{\text {st }}$ of January)

ripening cultivars ('Topaz', 'Florina', 'Rewena', 'Enterprise', 'GoldRush') (Fig. 1).

Despite the early time of harvesting, the cultivar 'William's Pride' had the largest fruit (206.8 g), and the cultivar 'Discovery' produced fruit with the smallest mass (144.5 g) (Tab. 3). Six cultivars had fruits larger than $70 \mathrm{~mm}$. Only the cultivar 'William's Pride' had larger fruits than the standard cultivar 'Idared'. The highest crop load and yield efficiency were shown by the cultivar 'GoldRush', and the smallest by the cultivars 'Discovery' and Selection 25/63. High generative potential, assessed by yield efficiency, ensured the highest value of yield per tree and unit land area. Over the study period, the cultivar 'GoldRush' produced the highest yield, while Selection 25/63 the lowest. Beber, (2009) had shown that among the examined cultivars 'GoldRush' produced a very small cumulative yield. This could have been because this cultivar manifested a very high value of the biennial bearing index. Also, the cultivar 'GoldRush' had the highest value of crop load and yield efficiency, and a high level of resistance to fire blight.

According to Saei et al. (2011), firmness is a primary measure of apple fruit texture, and a key determinant of eating quality of apples. The values

Table 3. Productivity of scab-resistant apple cultivars (2011-2015)

\begin{tabular}{lccccccc}
\hline Cultivar & $\begin{array}{c}\text { No. of } \\
\text { flower buds }\end{array}$ & $\begin{array}{c}\text { Fruit mass } \\
(\mathrm{g})\end{array}$ & $\begin{array}{c}\text { Fruit width } \\
(\mathrm{mm})\end{array}$ & $\begin{array}{c}\text { Crop load } \\
(\text { fruits cm } \\
\text { TCSA })\end{array}$ & $\begin{array}{c}\text { Yield } \\
\text { efficiency } \\
\left(\mathrm{kg} \mathrm{cm}^{-2}\right. \\
\text { TCSA })\end{array}$ & $\begin{array}{c}\text { Yield } \\
(\mathrm{kg} \text { per tree })\end{array}$ & $\begin{array}{c}\text { Yield } \\
\left(\mathrm{t} \mathrm{ha} \mathrm{C}^{-1}\right)\end{array}$ \\
\hline Discovery & $51.8 \mathrm{~b}$ & $144.5 \mathrm{~d}$ & $63.5 \mathrm{~d}$ & $3.2 \mathrm{c}$ & $0.62 \mathrm{c}$ & $8.3 \mathrm{~cd}$ & $19.0 \mathrm{~d}$ \\
William's Pride & $59.9 \mathrm{ab}$ & $206.8 \mathrm{a}$ & $75.4 \mathrm{a}$ & $4.05 \mathrm{c}$ & $1.26 \mathrm{ab}$ & $14.8 \mathrm{~b}$ & $33.8 \mathrm{~b}$ \\
Selection 25/63 & $33.4 \mathrm{c}$ & $189.6 \mathrm{ab}$ & $73.4 \mathrm{ab}$ & $3.4 \mathrm{c}$ & $0.59 \mathrm{c}$ & $6.6 \mathrm{~d}$ & $15.1 \mathrm{~d}$ \\
Prima & $68.3 \mathrm{ab}$ & $160.5 \mathrm{~cd}$ & $68.9 \mathrm{bc}$ & $4.45 \mathrm{bc}$ & $0.89 \mathrm{bc}$ & $12.6 \mathrm{bc}$ & $28.8 \mathrm{bc}$ \\
Champion & $58.5 \mathrm{~b}$ & $155.8 \mathrm{~cd}$ & $67.7 \mathrm{c}$ & $3.92 \mathrm{c}$ & $0.72 \mathrm{c}$ & $11.5 \mathrm{c}$ & $26.3 \mathrm{c}$ \\
Rewena & $54.8 \mathrm{~b}$ & $170.4 \mathrm{bc}$ & $71.1 \mathrm{ab}$ & $5.02 \mathrm{~b}$ & $1.01 \mathrm{bc}$ & $14.8 \mathrm{~b}$ & $33.8 \mathrm{~b}$ \\
Remura & $64.0 \mathrm{ab}$ & $165.7 \mathrm{c}$ & $70.4 \mathrm{~b}$ & $6.16 \mathrm{~b}$ & $0.82 \mathrm{bc}$ & $12.7 \mathrm{bc}$ & $29.0 \mathrm{bc}$ \\
Topaz & $48.2 \mathrm{~b}$ & $182.7 \mathrm{~b}$ & $72.3 \mathrm{ab}$ & $3.38 \mathrm{c}$ & $0.78 \mathrm{bc}$ & $14.7 \mathrm{~b}$ & $33.6 \mathrm{~b}$ \\
Florina & $48.5 \mathrm{~b}$ & $180.4 \mathrm{bc}$ & $69.7 \mathrm{bc}$ & $3.86 \mathrm{c}$ & $1.14 \mathrm{ab}$ & $15.7 \mathrm{ab}$ & $35.9 \mathrm{ab}$ \\
Enterprise & $70.7 \mathrm{a}$ & $181.2 \mathrm{bc}$ & $68.1 \mathrm{c}$ & $4.33 \mathrm{bc}$ & $0.99 \mathrm{bc}$ & $13.5 \mathrm{bc}$ & $30.8 \mathrm{bc}$ \\
GoldRush & $69.3 \mathrm{ab}$ & $168.5 \mathrm{~cd}$ & $70.8 \mathrm{~b}$ & $8.27 \mathrm{a}$ & $1.43 \mathrm{a}$ & $18.0 \mathrm{a}$ & $41.1 \mathrm{a}$ \\
Idared (control) & $53.6 \mathrm{~b}$ & $195.3 \mathrm{ab}$ & $73.4 \mathrm{ab}$ & $2.86 \mathrm{c}$ & $0.78 \mathrm{bc}$ & $12.5 \mathrm{bc}$ & $28.6 \mathrm{bc}$ \\
\hline
\end{tabular}

Data are means of 5 replications; different letters in columns indicate significant difference between cultivars according to Tukey's test at $5 \%$ level $(p<0.05)$ 
Table 4. Fruit quality of scab-resistant apple cultivars (2011-2015)

\begin{tabular}{llllllllll}
\hline Cultivar & $\begin{array}{c}\text { Firmness } \\
\left(\mathrm{kg} \mathrm{cm}^{-2}\right)\end{array}$ & $\begin{array}{c}\text { TSS } \\
\left({ }^{\circ} \mathrm{Brix}\right)\end{array}$ & $\begin{array}{c}\text { Maturity } \\
\text { stage }\end{array}$ & $\begin{array}{c}\mathrm{TA} \\
\left(\mathrm{g} \mathrm{dm}^{-3}\right)\end{array}$ & $\begin{array}{c}\mathrm{TS} \\
\left(\mathrm{g} 100 \mathrm{~g}^{-1}\right)\end{array}$ & $\begin{array}{c}\text { IS } \\
\left({\left.\mathrm{g} 100 \mathrm{~g}^{-1}\right)}^{2}\right.\end{array}$ & $\begin{array}{c}\text { Sugars/ } \\
\text { acids } \\
\text { ratio }\end{array}$ & $\begin{array}{c}\text { AA } \\
\left(\mathrm{mg} 100^{-1} \mathrm{FW}\right)\end{array}$ & $\begin{array}{c}\text { Surface } \\
\text { blush } \\
(\%)\end{array}$ \\
\hline Discovery & $5.9 \mathrm{c}$ & $13.7 \mathrm{c}$ & 0.21 & $0.80 \mathrm{bc}$ & $12.4 \mathrm{bc}$ & $10.9 \mathrm{bc}$ & 15.5 & $12.3 \mathrm{e}$ & 55.0 \\
William's Pride & $6.8 \mathrm{bc}$ & $13.5 \mathrm{c}$ & 0.19 & $0.50 \mathrm{c}$ & $12.6 \mathrm{bc}$ & $11.5 \mathrm{bc}$ & 25.2 & $16.8 \mathrm{~cd}$ & 85.0 \\
Selection 25/63 & $5.7 \mathrm{c}$ & $12.0 \mathrm{c}$ & 0.14 & $1.20 \mathrm{ab}$ & $10.4 \mathrm{c}$ & $8.9 \mathrm{~d}$ & 8.7 & $14.3 \mathrm{de}$ & 38.0 \\
Prima & $7.2 \mathrm{ab}$ & $13.7 \mathrm{c}$ & 0.15 & $1.10 \mathrm{ab}$ & $12.3 \mathrm{c}$ & $11.2 \mathrm{bc}$ & 11.2 & $18.9 \mathrm{c}$ & 40.0 \\
Champion & $6.9 \mathrm{~b}$ & $16.4 \mathrm{~b}$ & 0.13 & $1.30 \mathrm{a}$ & $14.6 \mathrm{~b}$ & $12.6 \mathrm{~b}$ & 11.2 & $25.4 \mathrm{ab}$ & 35.0 \\
Rewena & $7.7 \mathrm{a}$ & $14.1 \mathrm{bc}$ & 0.20 & $1.00 \mathrm{ab}$ & $12.8 \mathrm{bc}$ & $11.3 \mathrm{bc}$ & 12.8 & $21.2 \mathrm{bc}$ & 58.0 \\
Remura & $7.2 \mathrm{ab}$ & $14.8 \mathrm{bc}$ & 0.14 & $0.90 \mathrm{~b}$ & $13.2 \mathrm{bc}$ & $12.1 \mathrm{bc}$ & 14.7 & $14.2 \mathrm{de}$ & 85.0 \\
Topaz & $6.9 \mathrm{~b}$ & $18.1 \mathrm{ab}$ & 0.12 & $1.02 \mathrm{ab}$ & $16.7 \mathrm{ab}$ & $15.1 \mathrm{a}$ & 17.4 & $26.5 \mathrm{a}$ & 70.0 \\
Florina & $7.5 \mathrm{ab}$ & $18.9 \mathrm{a}$ & 0.11 & $0.60 \mathrm{bc}$ & $16.9 \mathrm{a}$ & $15.3 \mathrm{a}$ & 29.8 & $20.3 \mathrm{bc}$ & 70.0 \\
Enterprise & $7.4 \mathrm{ab}$ & $17.7 \mathrm{ab}$ & 0.16 & $0.78 \mathrm{bc}$ & $16.1 \mathrm{ab}$ & $14.5 \mathrm{a}$ & 20.6 & $15.6 \mathrm{~d}$ & 85.0 \\
GoldRush & $7.9 \mathrm{a}$ & $15.3 \mathrm{bc}$ & 0.18 & $0.70 \mathrm{bc}$ & $13.5 \mathrm{bc}$ & $12.6 \mathrm{~b}$ & 23.6 & $22.3 \mathrm{~b}$ & 12.0 \\
Idared (control) & $7.1 \mathrm{ab}$ & $14.3 \mathrm{bc}$ & 0.14 & $1.30 \mathrm{a}$ & $12.3 \mathrm{c}$ & $10.8 \mathrm{c}$ & 9.5 & $16.5 \mathrm{~cd}$ & 40.0 \\
\hline
\end{tabular}

Data are means of 5 replications; different letters in columns indicate significant difference between cultivars according to Tukey's test at 5\% level $(p<0.05)$; TSS - total soluble solids; maturity stage - the Streif index considering starch, sugar and firmness; TA total acids; TS - total sugars; IS - invert sugars; AA - ascorbic acid

of firmness are used to predict the durability in handling and storage properties of fruit (Šavikin et al., 2014). In apple, it is generally established that the lowest value of acceptable fruit firmness is 6-7 $\mathrm{kg} \mathrm{cm}^{-2}$ (Panzella et al., 2013). In our study, firmness values ranged from 5.7 to $7.9 \mathrm{~kg} \mathrm{~cm}^{-2}$ (Tab. 4.).

The maturity level of apple fruit depends on the amount of soluble sugars, organic acids, some inorganic substances and vitamins, and are an important indicators of the inner quality parameters of apple fruits (Mikulič-Petkovšek et al., 2009). The highest total acids was recorded in the fruits obtained from the cultivars 'Champion' and 'Idared', while fruits of the cultivars 'William's Pride' and 'Florina' had the lowest levels. The highest concentrations of total and reducing sugars were obtained in 'Florina' and 'Topaz' fruits. High correlation was found between total soluble solids and total sugar content $(r=0.767 ; p<0.001)$, and between soluble solids and reducing sugars $(r=0.617 ; p<0.05)$. The highest values of the sugars/acids ratio were shown by the cultivars 'Florina' and 'William's Pride'. All the cultivars, except Selection 25/63, had higher values of this parameter compared to the control. Significant influence on the values of the sugars/acids ratio was exerted by total acids in comparison with total sugars $(r=-0.91$ to $\mathrm{r}=0.67 ; p<0.05)$. Lata and Tomala (2007) had cited that ascorbic acid was an important quality characteristic of apple fruits, especially desired for its antioxidant properties. The values of ascorbic acid obtained in our study were in a higher range in comparison with commercial apple cultivars 'Elstar', 'Gala', 'Golden Delicious', 'Jonagold', 'Fuji' and 'Granny Smith' (Planchon et al., 2004; Drogoudi et al., 2008).

Phenolics are an important class of secondary metabolites in plants and can be divided into many subgroups such as hydroxycinnamic acids, flavonols, flavanols and anthocyanins (Treutter, 2005). Phenolic compositions of apple samples are presented in Figure 2. According to Tsao et al. (2003), five major groups of polyphenolic compounds are found in apple fruits: hydroxycinnamic acids (primarily chlorogenic acid), flavan-3-ols (epicatechin), flavonols (quercetin glycosides), hydrochalcones (phloridzin) and anthocyanins (cyanidin-3-galactoside). The monomeric and polymeric flavan-3-ols (about 60\%) and flavonols (about 18\%) represent the main compounds of the total phenolic concentration in apple peel (Lata et al., 2009). The total phenolic content of apple cultivars ranged from $209.2 \mathrm{mg} 100 \mathrm{~g}^{-1} \mathrm{FW}$ (Selection 25/63)

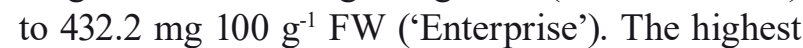
amounts of total phenolic acids were in the cultivar 'Champion' (55.2 mg $100 \mathrm{~g}^{-1} \mathrm{FW}$ ), while Selection $25 / 63$ contained the smallest amount $\left(6.5{\mathrm{mg} 100 \mathrm{~g}^{-1}}^{-1}\right.$ FW). Ceymann et al. (2012) had recorded similar values of phenolic acids in 104 European apple cultivars.

The cultivar 'Topaz', with $145.2 \mathrm{mg} 100 \mathrm{~g}^{-1}$ $\mathrm{FW}$, had the highest concentration of flavanols, while Selection 25/63, with $41.3 \mathrm{mg} 100 \mathrm{~g}^{-1} \mathrm{FW}$, had the lowest. Duda-Chodak et al. (2010) had reported lower concentrations of total flavanols in apple cultivars grown in Poland compared with 
total phenolics $\square$ total flavanols $\square$ total flavonols $\square$ total phenolic acids

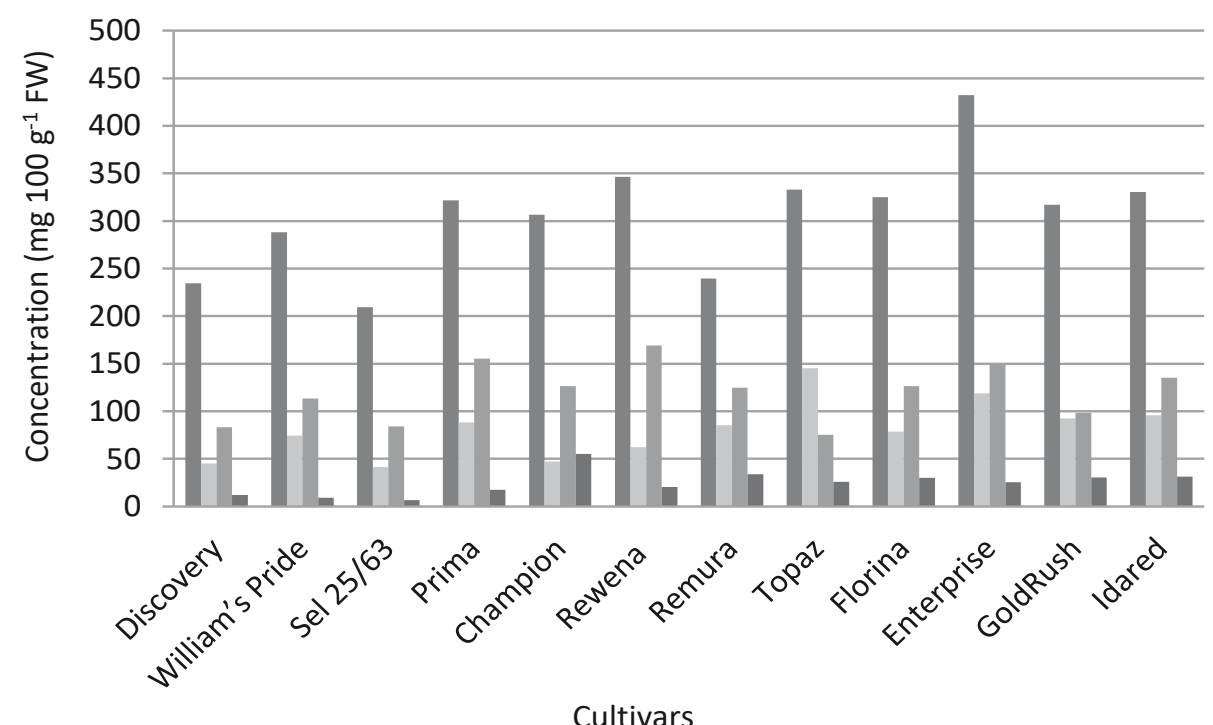

Figure 2. Concentrations (mg $100 \mathrm{~g}^{-1} \mathrm{FW}$ ) of total phenolics, total flavanols, total flavonols and total phenolic acids in the fruit of scab-resistant apple cultivars (2013-2015). Each mean represents the results of analyses of three independent samples

our results. The biosynthesis and accumulation of secondary compounds are dependent on growth and environmental conditions (Mikulič-Petkovšek et al., 2009). Also, the cited authors concluded that scab-resistant cultivars had a higher value of total flavanols. The flavonols were a major group of polyphenolic compounds found in apple cultivars (average for all cultivars was 39\% of total phenolics). The cultivar 'Rewena' had the highest values of total flavonols (169.2 mg $\left.100 \mathrm{~g}^{-1} \mathrm{FW}\right)$, while 'Topaz' had the lowest $\left(75.3 \mathrm{mg} 100 \mathrm{~g}^{-1} \mathrm{FW}\right)$. 'Topaz' was the only cultivar which had a smaller amount of flavonols in comparison with flavanols. According to Lamperi et al. (2008), the concentration of total flavonols depended on weather conditions and growing practices, and values ranged from 49.1 to $266.2 \mathrm{mg} 100 \mathrm{~g}^{-1} \mathrm{FW}$.

The tested cultivars and selection arranged according to the level of resistance to fire blight, from highly susceptible to highly resistant, are shown in Figure 3. As a result of artificial inoculations during the five-year study, only the cultivar 'GoldRush' showed high resistance, with the mean blight necrosis level of 5.3\%. Moderately resistant cultivars (blight necrosis 13-26\%) were 'Rewena', 'Prima', 'Enterprise' and 'Florina'. Moderately

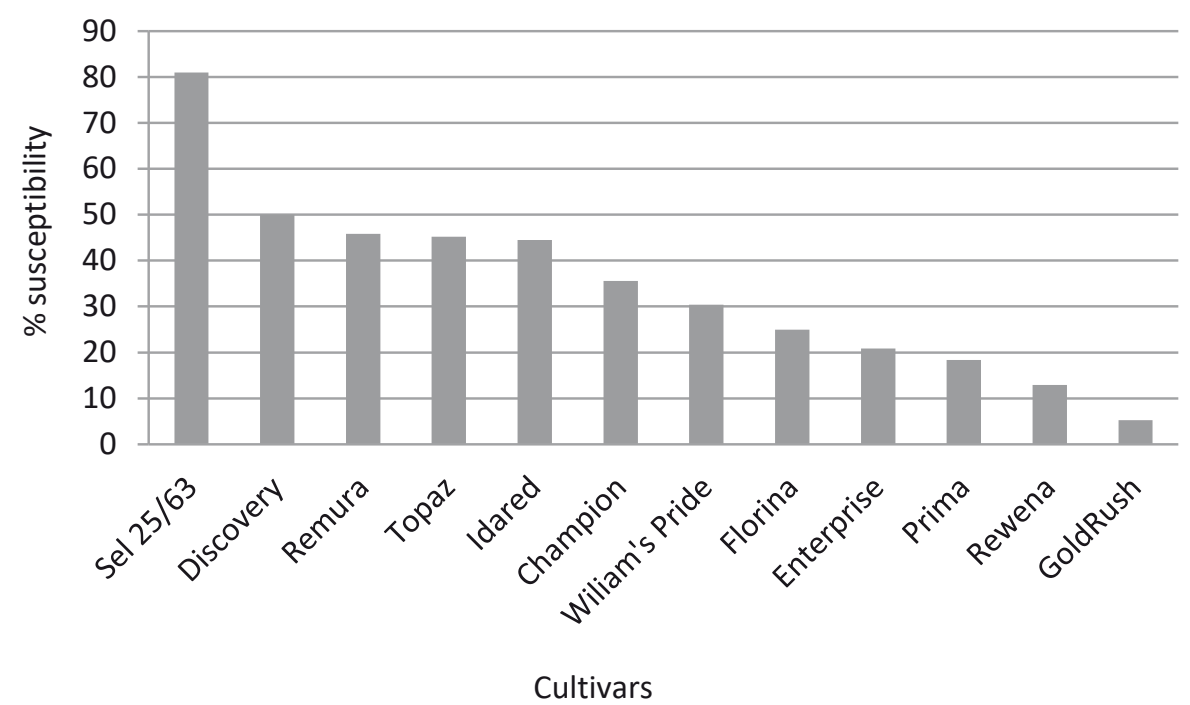

Figure 3. Fire blight susceptibility scores of apple cultivars after artificial inoculations. Each mean represents the results of analyses of five replications, each consisting of 20 trees 
susceptible (blight necrosis 26-60\%) were cultivars 'William's Pride', 'Champion', 'Idared', 'Topaz', 'Remura' and 'Discovery'. The most susceptible cultivar was Selection 25/63 (81\%). According to Korba et al. (2008), the ability of apple genotypes to exclude penetration by the fire blight pathogen, or suppress its activity after penetration can be strongly affected by the age, vigour, and nutrition status of the host, as well as environmental factors, particularly temperature and humidity. In our study, we recorded statistically significant correlations between the level of resistance and the values of total phenolics of the cultivars $(r=-0.68 ; p<0.05)$. The higher resistance to fire blight of the cultivars 'GoldRush', 'Remura', 'Prima' and 'Enterprise' could be a result of higher concentrations of total phenols and flavonols. However, no clear evidence of the direct role of this class of flavonoids in the general resistance of apple against diseases has been presented to date (Gaucher et al., 2013).

\section{CONCLUSIONS}

High generative potential ensured the highest value of yield efficiency, yield per tree and per unit land area. Seven cultivars produced higher average yields during the five years of research in comparison with the control cultivar. Five cultivars ('GoldRush', 'Florina', 'Topaz', 'Rewena' and 'Champion') had statistically significantly higher values of fruit quality parameters compared to the control. Total phenolics content of the apple cultivars ranged from $209.2 \mathrm{mg} 100 \mathrm{~g}^{-1} \mathrm{FW}$ to

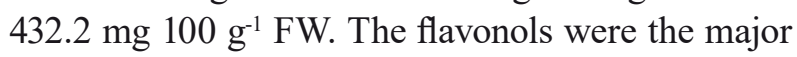
group of polyphenolic compounds found in the apple cultivars. The highest values of flavonols were in the cultivars 'Rewena' and 'Prima', while the cultivars 'Topaz' and 'Enterprise' contained the highest amounts of flavanols. Our results should be useful to growers, because we have identified the genotypes that are resistant or susceptible to fire blight. The cultivar 'GoldRush' showed high resistance to fire blight necrosis. Positive correlation between the total phenolic content and disease resistance was found. In the five-year study period, the cultivars 'GoldRush', 'Rewena' and 'Enterprise' exhibited relatively better bio-chemical properties and higher levels of resistance to fire blight.

\section{FUNDING}

This study was supported by the Ministry of Education, Science and Technological Development of the Republic of Serbia (projects No. TR 31063 and No. III 46013).

\section{AUTHOR CONTRIBUTIONS}

B.Đ., D.Đ., G.Z., T.V. and A.R. - designed experiments, analysed data and contributed to manuscript writing; B.Đ. and G.Z. - performed analysis of phenolic content and fruits quality; D.Đ. - analysed biological properties; T.V. and A.R. analysed susceptibility of cultivars to fire blight.

\section{CONFLICT OF INTEREST}

Authors declare no conflict of interest.

\section{REFERENCES}

Beber M., 2009. Characteristics of scab resistant apple cultivars. Proc. $2^{\text {nd }}$ Symposium Innovation in Fruit Growing, February 10-11, Belgrade, 129-137.

Ceymann M., Arrigoni A., Scharer H., Bozzi Nising A, Hurrell R., 2012. Identification of apples rich in health-promoting flavan-3-ols and phenolic acids by measuring the polyphenol profile. J. Food Comp. Anal. 26, 128-135.

Drogoudi P.D., Michailidis Z., Pantelidis G., 2008. Peel and flesh antioxidant content and harvest quality characteristics of seven apple cultivars. Sci. Hortic. $115,149-153$.

Duda-Chodak A., Tarko T., Satora P., Sroka P., TUSZYNSKI T., 2010. The profile of polyphenols and antioxidant properties of selected apple cultivars grown in Poland. J. Fruit Ornam. Plant Res. 18(2), 39-50.

Gunen Y., Misirli A., Gulcan R., 2005. Leaf phenolic content of pear cultivars resistant or susceptible to fire blight. Sci. Hortic. 105(2), 213-221.

HARRIS D.C., 2000. Using a PH electrode for an acidbase titration. In: Quantitative Chemical Analysis. D.C. Harris (Ed.), Freeman, New York, NY, USA, $37-40$.

JACKSON J., 2000. Apple production at low latitudes. In: Temperate Fruit Crops in Warm Climates. A. Erez (Ed.), Springer, Netherlands, 305-342.

Korba J., ŠIllerová J., KŮDela V., 2008. Resistance of apple varieties and selections to Erwinia amylovora in the Czech Republic. Plant Protect. Sci. 44, 91-96.

Kühn B.F., Andersen T.T., Pedersen H.L., 2003. Evaluation of 14 old unsprayed apple varieties. Biol. Agric. Hortic. 20(4), 301-310.

Lata B., Tomala K., 2007. Apple peel as a contributor to whole fruit quantity of potentially healthful bioactive compounds. Cultivar and year Implication. J. Agric. Food Chem. 55, 10795-10802.

Lata B., Trampczynska A., Paczesna J., 2009. Cultivar variation in apple peel and whole fruit phenolic composition. Sci. Hortic. 121(2), 176-181. 
Lauri P.E., Willaume M., Larrive G., Lespinasse J.M., 2004. The concept of centrifugal training in apple aimed at optimizing the relationship between growth and fruiting. Acta Hortic. 636, 35-42.

Li P., Castagnoli S., Cheng L., 2008. Red 'Anjou’ pear has a higher photoprotective capacity than green 'Anjou'. Physiol. Plant. 134, 486-498.

Mikiciński A., Sobiczewski P., Pulawska J., MACIOROWSKi R. 2016. Control of fire blight (Erwinia amylovora) by a novel strain 49M of Pseudomonas graminis from the phyllosphere of apple (Malus spp.). Eur. J. Plant Pathol. 145(2), 265-276.

Mikulič-Petkovšek M., Štampar F., Veberič R. 2007. Parameters of inner quality of the apple scab resistant and susceptible apple cultivars (Malus domestica Borkh.). Sci. Hortic. 114, 37-44.

Mikulič-Petkovšek M., Štampar F., Veberič R., 2009. Changes in the inner quality parameters of apple fruit from technological to edible maturity. Acta Agric. Slov. 93, 17-29.

Mikulič-Petkovšek M., Štampar F., Veberič R., 2009. Accumulation of phenolic compounds in apple in response to infection by the scab pathogen, Venturia inaequalis. Physiol. Mol. Plant Pathol. 74(1), 60-67.

Mratinić E., Fotirić-AKšić M., 2011. Evaluation of phenotypic diversity of apple (Malus sp.) germplasm through the principle component analysis. Genetika 43, 331-340.

Panzella L., Petriccione M., Rego P., Scortichini M., NAPOLITANo A., 2013. A reappraisal of traditional apple cultivars from Southern Italy as a rich source of phenols with superior antioxidant activity. Food Chem. 140, 672-679.

Planchon V., Lateur M., Dupont P., Lognay G., 2004. Ascorbic acid level of Belgian apple genetic resources. Sci. Hortic. 100, 51-61.

Radivojević D., Milivojević J., Oparnica Č., Vulić T., ĐorĐević B., ERcisli S., 2014. Impact of early cropping on vegetative development, productivity, and fruit quality of Gala and Braeburn apple trees. Turk. J. Agric. For., 38, 773-780.

Saei A., Tustin D.S., Zamani Z., Talaie A., Hall A.J., 2011. Cropping effects on the loss of apple fruit firmness during storage: the relationship between texture retention and fruit dry matter concentration. Sci. Hortic. 130, 256-265.

Šavikin K., Mikulič-Petkovšek M., Djordjević B., Zdunić G., Janković T., DuUrović D., Veberič R., 2013. Influence of shading net on polyphenol profile and radical scavengingactivity in different varieties of black currant berries. Sci. Hortiic. 160, 20-28.

Streif J., 1996. Optimum harvest date for different apple cultivars in the 'Bodensee' area. In: The Postharvest Treatment of Fruit and Vegetables: Determination and Prediction of Optimum Harvest Date of Apple and Pears. De Jager, A., Johnson, D., Hohn, E. (Eds.), COST, Brussels, Belgium, 15-20.

Tavarini S., Degl'innocenti E., Remorini D., Massai R., Guidi L., 2008. Antioxidant capacity, ascorbic acid, total phenols and carotenoids changes during harvest and after storage of Hayward kiwifruit. Food Chem. 107, 282-288.

Treder W., Mika A., KrzewińsKa D., 2010. Relations between tree age, fruit load and mean fruit weight. J. Fruit Ornam. Plant Res. 18, 139-149.

TreutTer D., 2005. Significance of flavonoids in plant resistance and enhancement of their biosynthesis. Plant Biol. 7, 581-591.

Tsao R., Yang R., Young J.C., Zhu H., 2003. Polyphenolic profiles in eight apple cultivars using high-performance liquid chromatography (HPLC). J. Agric. Food Chem. 51, 6347-6353.

Usenik V., Mikulic-Petkovsek M., Solar A, Stampar, F., 2004. Flavonols of leaves in relation to apple scab resistance. Z. Pflanzenkr. Pflanzenschutz. 111, 137 144.

Vanneste J.L., 2000. Fire Blight: The Disease and its Causative Agent, Erwinia amylovora. CABI Publishing, Wallingford, UK.

Veberic R., Trobec M., Herbinger K., Hofer M., Grill D., Stampar F., 2005. Phenolic compounds in some apple (Malus domestica Borkh) cultivars of organic and integrated production. J. Sci. Food Agric. $85,1687-1694$.

Received January 17, 2018; accepted August 23, 2018 